\title{
COMMUNAL LAND RIGHTS OF MALAY PEOPLE IN NORTH SUMATERA: POWER, STATE AND DEULAYATISASI
}

\author{
Edy Ikhsan*
}

* Teaching staff at Faculty of Law University of North Sumatera

\author{
Article Info \\ Received : 1 October 2014 | Received in revised form : 19 November 2014 | Accepted : 20 December 2014 \\ Corresponding author's e-mail : eikhsan@yahoo.com
}

\begin{abstract}
This article aims to unravel a shift of control / ownership of communal land of the Malays of Deli in North Sumatra. The commonly well-known communal lands, before the arrival of the Dutch colonial, was still inherent with the authorities of villages and was evolutionarily taken over by the foreign planters through concessionary contracts, which were dully signed by the Sultanate of Deli and the said foreign planters. The Indonesian independence in 1945 and the period that went beyond had in fact not contributed any improvement of the situation and instead it had exacerbated social and legal relations between the Malays of Deli and their ancestral lands. The said successful state laws had been so successful to keep these local natives away from their most important resource of life, namely their very lands. "Deulayatisasi" through state laws that was heavily oriented to the interests of capitalization to have seemingly been so successful to curtail the long journey of communal land rights in this country that seemed to have been pioneered by Van Vollenhoven during the early period of $20^{\text {th }}$ century. The customary land law, in Indonesia, will someday become a kind of a beautiful story in the course of historiographical laws of Indonesia.
\end{abstract}

Keywords: Communal Land Rights, Local Law, Melayu Deli Ethnic, Legal Pluralism, Capitalization

\begin{abstract}
Artikel ini bertujuan untuk mengungkap tentang peralihan kepemilikan tanah adat Melayu Deli di Sumatera Barat. Sebelum kedatangan colonial Belanda, tanah adat melekat dengan aparat desa dan secara perlahan diambil alih oleh pekebun asing melalui perjanjian konsesi yang ditandatangani antara Kesultanan Deli dengan pekebun asing. Kemerdekaan Republik Indonesia pada tahun 1945 dan masa setelahnya tidak berdampak pada perbaikan keadaan, dan sebaliknya memperburuk hubungan social dan hukum antara Melayu Deli dan tanah leluhur mereka. Undang-undang nasional berhasil menjaga masyarakat adat jauh dari sumber daya hidup yang paling penting, yaitu tanah."Deulayatisasi" melalui Undang-undang nasional berorientasi berat pada kepentingan kapitalisasi tampaknya begitu berhasil untuk membatasi perjalanan panjang dari hak ulayat di Negara ini yang dipelopori oleh Van Vollenhoven pada awal abad ke-20. Hukum tanah adat di Indonesia pada suatu hari akan menjadi semacam cerita indah dalam perjalanan hukum historiografis Indonesia.
\end{abstract}

Kata kunci: Hakulayat, hukum adat, etnis Melayu Deli, pluralism hukum, kapitalisasi

\section{Introduction}

In almost a hundred year ago, Van Vollenhoven, the most paramount pioneer in the area of Customary Law in Indonesia, created a terminology in which the impulse to the present day remains to be felt and has been strongly being lingered, and even stronger and faster after the reform of 1998. The said terminology is what is so called: Het Beschikkingsrecht, by which then it is translated as Communal Land 
Rights (Communal Rights). Van Vollenhoven has described the so called communal land rights as:het hoogste recht ten aanzien van grond (the highest rights over land). ${ }^{1}$ Regardless of criticism launched by Burn $^{2}$ very recentlyaround anthropological doctrines as already invented and developed by Van Vollenhoven (mainly terminology on communal rights), academic societies and the advocates of communal lands have to give special appreciation to this Dutch scholar over his meritorious service in uplifting the importance of communal land rights of indigenous people in the Netherlands East Indies to be in parallel with the western civil rights, in which present times dominating our social life.

The emergence of communal land rights in what is so called Kolonialerechstermen has become an ember in a hull of rice in the history of land capitalization in the Netherlands East Indies. The industrialists have tirelessly worked together with academic groups in University of Utrecth (under the direction of Nols Trenite) and fully involved in encouraging a change of policy on land in this said region. The emergence of Article 1Agrarisch Besluitin 1870 as a rule of implementation for the Agrarische Wet, which was emphasizing that all lands whose ownership cannot be proven by any persons, such lands (domein) shall be belonged to the state (dat alle grond, waarop niet door anderen recht van eigendom wordt bewezen, domein van den staat is), was supposed to be a peak of success resulted from the tandem provocation made by the Dutch academic and industrialists during that period.

Such a land with the very distinctive characteristic, which is community-base owned and is hardly ever known in European laws, has seriously experienced qualitative degradation ever since the legal transplantation (read: compulsion) by the Dutch and the ambivalent politics being exercised by a regime of Indonesian administration during the post period of independence of August 1945. Countless number of rules was adopted to dismiss one of the most distinctive and deeply rooted ownership rights and with the rules being imposed; they have uprooted it from the deepest marrow within the life of indigenous people all over Indonesia. As a matter of fact, with formal and normative efforts that have ever been imposed, they have not been able so successfully and to totally dismiss the collective memories of the people in light of the primordially descended rights of lands ever collectively owned.

In North Sumatera, the indigenous groups of people falling under the category of Malay ${ }^{3}$ ethnics, also experienced the same situation. There were at least the communal lands in the four Sultanates ${ }^{4}$ of Malay in Eastern Sumatera came along to be reduced by imposition of colonial regulation and even bitter situation by the compulsion of rules enacted by the state of Republic of Indonesia - despite the historical fact that the sultanates to have provide moral support during which time this country was proclaimed in 1945.

This paper is aimed at briefly tracing the historical ups and downs of understanding, recognition as well as protection - het beschikkingsrecht, most especially in eastern

\footnotetext{
${ }^{1}$ Van Vollenhoven, De Indonesiers en Zijn Grond, Leiden, Brill, 1919. p.9

${ }^{2}$ Further, see Burns, Peter. The Leiden Legacy: Concepts of Law in Indonesia. Leiden, KITLV Press, 2004.

${ }^{3}$ Malay ethnic consists of a tribal group that inhabit Eastern Coast of North Sumatera beginning from the district of Eastern Aceh, Langkat, Deli Serdang, Serdang Bedagai, Batubara, Asahan until Labuhan Batu. Husny quoted this as a tribal group that amalgamated itself in a mixture of inter-ethnic marriage ties by consciously making use of Reusam Tradition and the Language of Malay in sustainable ways. Husny, Lah. Historical Track of Civilization and Tradition of Deli Coastal Malay of Eastern Sumatera 1612-1950, Jakarta: Department of Education and Culture, 1978: p.25.

${ }^{4}$ The Sultanate of Langkat, Deli, Serdang and Asahan.
} 
coast of North Sumatera region (formerly was famous to be termed as Oost Kust van Sumatra (Eastern Sumatera) - by way of tracing or scrutinizing over various regulations, which are directly or indirectly related to the accounts of events. At the very end part, this paper will address the needs of legal protection over communal lands with the binding certainties, by means of at least using higher degrees of state's regulations and urgency of related regional regulations.

\section{From Oetan Tanah, Reba until Tanah Jaluran: The Position of Communal Land Rights of MalayEthnic Before and After the Coming of Dutch Colonials}

Mahadi introduced the term Oetan Tanah, which he quoted from Pandecten van het Adat Recht, to describe a form of communal land along the coast of eastern Sumatera. ${ }^{5}$ His conviction is confirmed by his own findings from various notes of The Commission of Indigenous Laws by affixing the word beschikkingsrechtat the back of word Oetan Tanah. ${ }^{6}$ From the mention of word Oetan (forest), it at least describes a fact that a plot of land which encompasses a group of communal lands herein is a forest area that is located surrounding the life of Malay people as stated beforehand. This really makes sense in light of social life, which was not like the present day. Utilizing the forest as the sources of life support system (such as: water sources, hives, etc) as an important and common coping strategy. Slaats and Portier for instance, found the term kerangen (forest) among Karonese People in North Sumatera to indicate a forest area where any utilization done by outsiders should involve a permit of approval from a chieftain of the kampong (dit ging dan altijd op grond gedaan verzoek aan het dorpshoofd en na verkregen toestemming). ${ }^{7}$

Various written sources narrated some empirical facts of concepts and characteristics of communal lands in the areas of eastern coast. Ridder for instance has exemplified a condition of communalism applied among the people in the eastern coast of Sumatera by quoting a report that a land holds communal characteristic in nature. In the event that someone has chosen a plot of land to be cultivated, he or she must obtain permit or approval from the chieftain of the Kampung. The obligation/ tasks of community (the adults) should involve: a. Keep security of the kampong; b. Constructing a house for the kind and providing all materials for the building; $\mathrm{c}$. Plowing and cultivating the lands for the interests of the kings and other chieftains; e. Escorting the king when they are travelling. ${ }^{8}$

According to Bool, any lands that have been long cultivated by resident, would have to be private ownership. Anyhow, if they are not cultivated the land would again become common property. The lands that had become private property were often taking place to Reba lands of farmlands, which were normally located at the edge of the border around the vicinity of village areas. All descendants of the cultivators were entitled the rights to cultivate such lands - whilst residents coming from outside of the village would have not been entitled to any rights at all unless otherwise be given

\footnotetext{
${ }^{5}$ Mahadi,Chronicles on the Development of Tribal Rights Over Communal Lands in Eastern Sumatera (1800-1975), Bandung, Alumni Press,1976, p. 91.

${ }^{6}$ Ibid.

${ }^{7}$ Slaats, HMC and MK. Portier. grondrecht en Zijn Verwerkelijking in de Karo Batakse Dorpssamenleving. Nijmegen, Ge Nabrink \& Son, 1981. p.84.

${ }^{8}$ De Ridder.J. De Invloed van de Westersche Cultures op de Autochtone Bevolking ter Oostkust van Sumatra, Wageningen: H.Veenman \& Zonen, 1935, p.16-17.
} 
permits. In addition, the residents of Malay ethnic who were often moving around to set up new villages so long as the former village was still cultivated, the land would remain to be owned by them. Such situation was often wrongly interpreted by western entrepreneurs who were searching for strategic and fertile lands in purpose of opening and planting commercial plants. ${ }^{9}$

In Langkat, as quoted by Mahadi, felling or damaging a tree so called Tualang tree (Purple Millettia: Millettiaatropurpurea) was considered a prohibited act because bees loved to nest in this tree. This prohibition was based on the fact that common people would normally harvest honey-bee and wax. Such a prohibition was in harmony with the characteristic of rights to communal lands that common people were granted free rights to make use of forest products (for their own needs, pen.). ${ }^{10}$ In this said area, when someone really wanted a big tree to make use of it as a material to make a boat, most especially he or she just had not had an opportunity to cut it, the intended tree would be given special treatment by peeling the barks of it open as wide as fingers around the stem which served as a sign of prohibition against other people to take control of the intended tree. ${ }^{11}$

Almost all historical records and documentation on customary law ever available were clearly indicating people's position and along with their chieftains, even at the lowest levels, to hold the highest authority over that was termed as communal lands, customary lands and until a certain extent to cover what was called as the existingwoeste landalong the Eastern Coast of North Sumatera, which served as a home for the ethnic group who was referred to as a Coastal Malay people. The politicking and the struggle of power space as shown by Reid ${ }^{12}$ and Stoler ${ }^{13}$ successfully pushed the existing chieftains to reach their positions as the representatives or the intermediary, the highest chieftains who served as symbols for safeguarding the customary and religious values of Malay people, some of which during that period was still at a relatively low level quality of life.

The harmony of people's life was relying on local customary tradition along with the available political power structure (the kings along with the high-ranks officers, the Datuks and village chieftains) was all of a sudden to be eventually displaced by the influx of foreign planters during the third half of the $19^{\text {th }}$ century. The concession (long term leasing or contracts of land use) that was made between the Sultanates and the foreign planters was forming the initial legal events that changed the formation of land-use control and utilization of communal lands belonging to the Malay people in this region.

The Concession Act, according to some scholars such as Mahadi, Rays, Perret and Pelzer to mention some of them, which served as the best source to see the colonial recognition and the Dutch Entrepreneurs with regard to the rights of communal lands of the Malay people in this region, could not be blamed whatsoever. However, none of the scholars mentioned earlier to have seen in details like Buffart who claimed that the concession act was of a normative incidence that was causing the indigenous people of the land owners to have been severely displaced of their own lands, most

\footnotetext{
${ }^{9}$ Bool.H.J. Landbouwconcessies in de Residentie Oostkust van Sumatra (without year and place) p. 62.

${ }^{10}$ Pandecten van het Adat Recht IV, p. 751

${ }^{11}$ Ibid. See also, Mahadi. Loc.cit.

${ }^{12}$ Reid, Anthony. People's Struggles:Revolution and Revolusi and the Destruction of Kingdoms in Sumatra. Jakarta: Sinar Harapan, 1987.

${ }^{13}$ Stoler Ann, Laura, Capitalism and Confrontation in Sumatra's Plantation Belt, 1870-1979. The University of Michigan Press: 1985.
} 
especially with regard to the real substance and contents of the concession. It was further mentioned that the concession was of a trap to annihilate people's position, most especially those who lived in villages to cultivate their own lands. ${ }^{14}$

The concession contract was clearly by fact a concept fully conditioned by the ideas of the Dutch and wholly contributed as an initial experiment for the influx of foreign elements at the normative level herein. Labberton ${ }^{15}$ showed how the capitalistic nature contained therein the conditions of the contract; some of the conditions were like the following: a. the contract entered into force prior to the approval from local government; $b$. to the most extent possible, the contract was implemented managed by themselves; $c$. the contact could not be handed over prior to the approval from the government; d. the people's existence within the concession area was not allowed; e. the workers to be employed and obtained voluntarily.

Other colonial paradigm, which also had implication on matters with regard to land issues and its relationship with the local people, was in the understanding of woeste grond or waste land. The interpretation used by the Government of East Indies on woeste grondwas clearly showing a "Western" perspective on lands. With the so called woeste grondit was meant that was covering the uncultivated lands or to some extent the land that was not worked on by the indigenous population and that of not considered as common property - or that of not considered under the reign of village chieftains (gronden, niet door de inlanders ontgonnen, noch als gemeene weide of uit eenigen anderen hoofdetot de dorpen behoorende). ${ }^{16}$

The so called Woeste grond was actually becoming the land object in context of the said concession. The forest lands, the wild land, the unused lands, the unattended lands, the uncultivated lands or any lands regardless of names, were types of lands being put in concession to the Dutch onderneming by the Sultanates in Eastern Sumatera, some of which might be falling within areas belonging to the villages (kampong) along with the structure of communal organizations underneath. These were the lands called by Kleintjes ashet recht,hetwelk tot inhoud heeft de bevoegheid van een inlandsche gemeenschap - hetzij een territoriale als een dorp of dorpenbond, hetzij een genealogische als een stam om aan zichzelf en haar leden het recht toe te kennen binnen een zekeren gebiedskring den woestgebleven grond naar goedvinden in gebruik te nemen en aan anderen it recht toe te kennen, alleen met haar toestemming tegen betaling van retributie of een huldegift. ${ }^{17}$ (The lands by which the power rest upon the indigenous population, which was territorial in nature as a village or a unit of village that was genealogically as a tribe that granted rights to the members of the village community to use the blank lands as well as to outside users with approval and payment of retribution or as a giving in the form of honorary gift).

The combination of concessional traps and the increasing adherents of land acquisition through the regulation imposed by the East Indies (which will be shown in next pages) would only give a little space to the indigenous community to cultivate

${ }^{14}$ Buffart, J.F.A.M. Rechten van de Bevolking op in Landbouw Concessie Uitgegeven Gronden. Overdruk uit "Indische Gids", July - Aflevering 1933. See also, Ikhsan, Edy. When the Pestle is Broken, the Mortar is certainly gone:The Shifting of Rights of Communal Land and Legal Pluralism within the Perspective of Socio-legal (The Study on Deli-Malay Ethnic in North Sumatra), Dissertation Summary, Doctoral Study Program (S3) Legal Studies, Law Faculty of North Sumatra University, Medan, 2013.

${ }^{15}$ Labberton, K. van Hinloopen. De Indische Landbouw consessie. Amsterdam, JH. De Bussy. 1903.

${ }^{16}$ Lekkerkerker, J.G.W. Concessie en Erfpachten ten behoevevan Landbouwondernemingen in de $\mathrm{Bu}-$ itengewestenvan Nederlands Indie, Groningen-Den Haag, JB.Wolters, 1928 p. 71.

${ }^{17}$ Kleintjes. Staatsinstellingen van Nederlandsch- Indie. Amsterdam, 1924, p. 294. 
and manage the already opened primordial lands, a heritage passed down from their ancestors. One amongst the opportunities was what so called in the literature of land history in Eastern Sumatera as tanah jaluran. It was of a land ex-tobacco planted areas submitted to the opgezetenen (indigenous inhabitants) to be cultivated with rice and/or corns within a certain period of time (previously for as long as one year then changed to be within one harvest season $)^{18}$ Every household of the population received 0.6 hectare of tanah jaluranfor one year of cultivation, a fertile land with fertilizers meticulously prepared and generally was quite arable. Such a width could produce harvest as much as 1920 kilograms (600 gantang)of rice with less workers ${ }^{19}$.

The opportunity to obtain the utilization of tanahjaluran, which was quite fertile had lessened the desires of Malay farmers in gaining a plot of land as much as 4 Bahu - more or less measuring 2,5 hectares, which still consisted of bush area that served as a substitute for the plantation opening, for such a land needed more hoeing and processing and required more energies/workersthat normally with less harvest or produce. The Malay farmers who obtained Tanah Jaluran could cultivate the lands by themselves or just put them on rent to the Chinese or the Javanese. In the era before 1920, there was only much of the ex-tobacco planted areas or Tanah Jaluran being required, and every demand tending to refuse would soon be superimposed much wider portion of the Tanah Jaluran to soften the main stance of chieftains mainly those who are very influential. In later concession contract, the providence of TanahJaluran was stipulated or listed as the obligation of plantation's owners.

Matters related to Tanah Jaluran have not been as simply as one can read from secondary elucidations. The demand over the land for the expansion of plantation areas, the increasingly narrowing land-use following the chaotic land allotment for indigenous inhabitants had caused the termination of further land allotment in 1930. In a more progressive perspective, it was difficult to accept the facts that the Malay People whom actually the owners of the communal lands had to do begging before the Dutch entrepreneurs in order to obtain a piece of land to cultivate in subsistence to survive their lives.

Later in 1953, the Malay People who were directly related to the so called TanahJaluran assembled and organized themselves to form an organization, which later well known as The Indonesian League of Indigenous People Struggle (BPRPI). This organization is to fight back the recognition over the land being put on rent to foreign enterprises (mainly of the Dutch) for tobacco plantation in covering the areas between Sei Wampu in Langkat and Sei Ular in Serdang Bedagai. In the next chapter of its mission, the struggle became harder when the Nationalization Law No. 86 of 1958 on Dutch-owned Enterprises was enacted. The State took over all the said lands.

\section{III.Structural Deprivation: FromDomainnota, Nationalization until The Main Agrarian Law of 1960}

${ }_{18}$ Three studies with respect to the Jaluran Lands within the beginning period of 21st century can be seen in Bool.H.J. Landbouwconcessies in de Residentie Oostkust van Sumatra., Jansen, Gerard. Granrechten in Deli. Uitgave van Sumatra-Instituut. 1925 dan Buffart. Op. cit.(1933). Each of the autonomous area had its own rules and regulation on whom is meant by what they termed it as Rakyat Penunggu. The regulation regarding the Rakyat Penunggu (Ra'jat Penoenggoe Regeling) in 1924 applied in the Sultanate of Serdang, there was at least 9 groups to be categorized as "de rechthebbenden op djaloeran" (the right holder of jaluran). See further, de Ridder. Op. cit. p.46. Mahadi, Op. cit p.149-151. Perret, Daniel. Kolonialisme dan Etnisitas: Bataknese and Malayin North Eastern of Sumatra. Jakarta, Kepustakaan Populer Gramedia, 2010. p. 206-207, following Bool, H.J. quoted 10 groups.

${ }^{19}$ Husny, Lah. Op. cit.. p.90. 
A political friction in the Netherlands was happening coincidentally with the organizational arrangement in the East Indies with regard to the best ways to do exploit colonial lands. The demand for a constitutional change was constantly raised, mainly from liberal groups. The liberal groups were not satisfied against the King's and the ministers' policies (that before 1840 truly rooted from conservative groups) who would perpetuate the extensive power of the king, either within home countries or within colonized lands. Both of these ideologies essentially considered the colonized areas as the object of exploitation of colonial countries. Somehow, only the conservative stream that wished the exploitation by the state (staatesploitatie) was implemented by means of forced planting model (cultuurstelsel). Whilst, the liberal stream wished the natural resource exploitation in colonized land be conducted by private initiatives by way of private investments in colonized lands as basis for the development of transport, trading, industries and banking enterprises.Minister van Kolonien de Waal, in 1869, proposed an idea of Wet in order to add article No. 62 RR $1854^{20}$ with the same purpose that was perpetuating the capitalization of lands in East Indies. Finally, the proposition was approved by Staten Generaaland became Weton $9^{\text {th }}$ April 1870 (Ind. Stb, 1870 No.55). With the article 62 of the Wet (Agrarische Wet), RR following with the 5 new verses that was opening up for the foreign private sectors to obtain material ownership rights (eigendom, opstal, erfpacht) over Indonesia own land and uncultivated or blank lands. The basic principles as stipulated within the article 62, were elucidated further byAlgemeene Maatregel van Bestuur (AmvB), Ind. Stb.1870. No.118, which later on to be well knows asAgrarisch Besluit, following the other implementingregulation. ${ }^{21}$

As an implementing regulation for the Agrarische Wet, Article 1 of Agrarisch Besluitof 1870, stipulated in the event that a land cannot be proved for its ownership by any person, then such a land becomes the property (domein) of the state (dat alle grond, waarop niet door anderen regt van eigendom wordt bewezen, domein van den staat is). Prior to the adoption of the Agrarisch Besluit, the understanding about domein related to the territorial areas directly controlled by the state was relatively narrow. In such a case, it was made different between the land of Free State(vrije domeinen; vrij landsdomein) and the land of controlled state (onvrije domeinen; onvrij landsdomein).

Article 9 of the Stb 1870 No. 118 expressly determines the lands that cannot be imposed with theerfpacht, namely: a. Any land on which there were the rights of others (Gronden waarop anderen hebben Regt), unless otherwise they do not want to use those rights, b. Any lands regarded by the natives as to have magic relationship (gewijde) by the natives; c. Any land procured to be markets or any procurement for the wide public (openbare Markten of openbare dienst bestemd) d. Coffee plantations belonging to the Government. e. Any lands planted with teak trees/other forest trees; f. any land located within the area of the Governor-General, which was set out to be planted with government's plants; g. Any lands reserved for the development of coffee

20 Article 62 verse 6 the RR stipulated: Lands used and cultivated by indigenous people for the their own shake and consent, or those under the category communal lands or by other means came into the ownership of the existing villages, can only be owned by the Governor General on reason for public necessity, through the application of article 133 (on revocation of land rights) and was conducted in accordance with certain conditions and with proper compensation.

${ }^{21}$ AmvB 1870, LN 118 namelyAgrarisch Besluit. Unlike the Agrarian Law, this Besluitcould only be applied upon colonial government land acquisition In Java Island and Madura. For the general setting upon other areas outside of Java and Madura, the Agrarische Reglementenwas applied (Agrarian Regulation). 
plantations. ${ }^{22}$

In this respect, only the land of a free state that was considered as belonging (domein) to the state, which included therein the civil rights of the state over it. Meanwhile, land of the controlled state comprised any land on which there were inherent communal rights and the land on which an absolute property rights was granted based on the Civil Code (Burgerlijk Wetboek). The underlying question in such a case may arise, namely: which of people's rights are regarded to be under the jurisdiction of the state's domein and which are not? This question also could not be answered, which was mainly due to the different conception (obscurity) on what the already considered by the colonial government as thevrij en onvrij landsdomeinwas in fact different from what had been interpreted or understood by the native indigenous people along with customary chieftains.

Beyond 1870, especially after Domeinnota was enforced on 1916, doctrines of the Domein in a broader sense had been well accepted in general. ${ }^{23}$ Consequently, not much of the customary rights of the indigenous people was recognized as well as granted by law. In other words, the span of the state power by means of the principles of the Domein becomes so extensive. ${ }^{24}$ In lights of broader exegesis, then normally the Domein declaration has been read as such (referring to article 520 of the Civil Law) signifying the uncultivated lands and those of no owners would be considered as the property of the state. In this way, it was totally different from the initial exegesis that was only giving authority to the state upon what was so called vrije landsdomein. In addition, with such an exegesis, the state had penetrated into the areas/lands, which was ever since to be claimed as communal lands and the like (onvrije landsdomein), so long as they it could not be proved by any parties that claimed for it. ${ }^{25}$

With the adoption of the Agrarische Wet and theAgrarisch Besluit in 1870, the regime of the new agrarian affairs in West Indies was officially implemented. This regulation was in the beginning applied to the lands directly under the control of the colonial government in Java Island including Madura. In later years, what was called the "Agrarian Affairs" (Agrarische Reglementen) began to be implemented outside of Java and Madura and it also included all determination with regard to the people's rights of customary law upon lands. In 1875, through Stb. Ind. 1875-199ait was decided that the agrarian law was also fully applicable to colonial lands outside of Java Island and Madura. In this way, the Domein Declaration was fully applicable to all

\footnotetext{
${ }^{22}$ The mention for land that cannot be rented was reinforced again by the issuance of Stb.1872 No.116, wijziging van het Koninklijk besluit, opgenomen in Indisch Staatsblad 1870 No.118.

${ }^{23}$ In 1916 Domeinnota (Memorandum Domein) was issued. The Domeinnota was made by a bureaucrat from the Ministry of G.J.Nolst Trenite and was issued as appendices along with Agrarisch Reglement voor de Residentie Sumatera's Westkust met toelichting. Batavia:Landsdrukkerij 1916. Ever since that time, the Domeinnota was considered as to represent the government's view on ways of properly interpreting and applying the so called Doktrin Domein.

${ }^{24}$ See Termorshuizen-Arts, Marjanne. Indonesian's People and Their Lands: The Development of Doktrin Domein During Colonial Time and Its Influences in the Indonesian Agrarian Law, in Safitri, Myrna A and Tristan Moeliono. Agrarian Law and Indonesian People. Jakarta, HuMa, Van Vollen Hoven Institute and KITLV-Jakarta. 2010, p.39.

${ }^{25}$ Article 520 BW in East Indies, according to Termorshuizen-Arts, had actually to be read as an affirmation that the uncultivated lands and the disowned lands would be considered as the lands belonging to the state. The enactment of article $520 \mathrm{BW}$ had brought implication to the state to prove that such lands were indeed uncultivated and disowned by anyone. Only in such a case then the state could claim itself as to be the owner of the lands.However, as a matter of fact, the Deklarasi Domeinof the East Indies version had reversed the obligation of prove-making: Not of the obligation of the state to make a proof, but any one claiming the ownerships that should provide the proof himself as the legal owner of the lands. Ibid. P.40.
} 
territories directly under the power of the East Indies government (Algemene Domein Verklaring). ${ }^{26}$

In Eastern Sumatera, the expansion of the first colonial constitution prior to the adoption of Stb 1875 No. 199a, the declaration on the adoption of Agraraisch Besluit, in the outside of Java island and Madura was made through the Staatsblad 1874 No. 94f under a title: "Wild Lands in Sumatera", Regulation on the release of the uncultivated lands within the territory of the Government in Sumatera. In his consideration, the Governor General, on behalf of the King (Sri Ratu) stated the Staatblad was issued in order to avoid some doubts over the rights of the state upon the wild lands (woeste landen) in the territory of government in Sumatera and also to confirm regulations to release such lands in the form of erfpacht (long terms leasing).Article 1 of the Staatsblad stipulated that all wild lands within the territory of Government in Sumatera, providing that the native indigenous people did not apply any rights deriving from the opening of the land (ontginningrecht), including the lands belonging to the state (staatsdomein). All lands that were included in the land belonging to the state, other than the rights of the land opening, the ownership was owned by the Government.

The Government of the East Indies was seemingly very careful to enforce the regulation of Agrarisch Besluit over the wild lands outside of Java and Madura. The involvement of the Native People in the Assessing Committee for the release of the erfpacht to the Dutch people and people of the East Indies indicated efforts of avoiding land related conflicts against some leaders of communities. ${ }^{27}$ Event, actually, the, Stb.1874 No.94f, and also the stb.1888 Mo.58 for Manado and the southern and eastern parts of Borneo, were included within the hidden rules (geheim). This rules were hidden (not publicized for wide public) in order to prevent the emergence of rebellions. However, by facts, the $19^{\text {th }}$ and $20^{\text {th }}$ centuries had witnessed so much protest and confrontation from the native indigenous people over the exegesis and the adoption of the Domein Declaration. ${ }^{28}$

In relation to the Residency of the Eastern Coast of Sumatera, by fact, the Stb.1874 No.94f was only enacted 2 years after it was first released. This indicated the prudent principles in the case. Such cases were demonstrated through a letter issued by the Council of East Indies on $12^{\text {th }}$ May 1876. The council considered that in lights of article 1 Stb 1874 No.94f, that it was beyond any reasonable doubts that the regulations on the release of the wild lands within the erfpacht as contained therein the regulations to be stipulated as applicable upon the wild lands within the territories of government in all Sumatera, and in this way it was also applicable upon the Residency of Eastern Coast of Sumatera and other islands by which administratively were falling into the territory of Sumatera. ${ }^{29}$

${ }^{26}$ Termorshuizen-Arts, Ibid. P.43-44. The core essence of the application of the Agrarisch Besluitfor areas outside of Java and Madura stipulated: Article 1 van het Koninklijk Besluit van 20 Julij 1870 No.15 Indisch Staatsblad No.118) is, behoudens het bepalde bij het tweede lid van artikel 27 van het reglement op het beleid der Regering van Nederlandsch Indide, ook van toepassing op de Governements landen in de bezittingen buiten Java en Madura.

${ }^{27}$ Later through Staatsblad 1891No.4, the Government completed the requirements of the certificate of land measurement and maps that would be proposed for the rights of erfpacht, again and again it was meant as in avoidance of land dispute against the indigenous people.See also Staatsblad 1891 No.5, on rules and regulation considered in the application of erfpachtover the lands claimed by the state in areas outside of Java and Madura.

${ }^{28}$ Termorshuizen-Arts, Op. cit. p.46.

${ }^{29}$ The advice of the Council is based on the Letter of the State secretary No. 908 on the enactment of 
Various efforts to reduce the rights of Customary People of Malay in the Eastern coast of North Sumatra continued to be done in the post of the power shifting from the Dutch and the Japanese to the hand of Republic of Indonesia through various rules and regulation imposed by ruling regimes. The very rich lands for various agricultural products became "game" between the Dutch and the Republic of Indonesia. The existing power of the rich Sultanate in the eastern coast of Sumatra did not seem to become options to be considered.

The worries of the Dutch upon the rights and properties owned by its private enterprises in Indonesia in the post of independence were clearly obvious to be seen from how they tried to reconstruct the structure of protection over those enterprises through the Linggarjati Accord signed on March 25, 1947. In the article 14 of the said accord it was stipulated: The Government of Republic of Indonesia recognizes the rights of non-Indonesian to regain their frozen rights for restoration and their belongings, which are under the ruled territory, shall be returned. A joint committee will be formed to implement such a restoration."

However, according to van de Kerkhof, the idea of article 14 was only a delusion that could be so far implemented to provide protection over the Dutch-owned enterprises in Indonesia. "The opposition of the Indonesian nasionalists and militant labour unions, illegal occupations of estate lands ("squatting") and the unwillingness of Dutch authorities to withdraw their troops made implementation of article 14 a slow and frustrating process."Four months after the Linggarjati Accord to be agreed, the Dutch launched its first aggression (July 1947) using a codeword "operation product", with the main intention to secure its estate enterprises and potential oil fields in Java and Sumatra. The said operation succeeded in "securing" about 1000 plantations and factories despite many of them had been broken and dysfunctional. ${ }^{30}$

In the end of the fifties, the Dutch-Indonesia political polemics, which implicated toward the unclear ownerships of communal lands, was ended along the issuance of Law No. 861958 on the Nationalization of Dutch-owned Enterprises. The article 1 of the said law was the real essence the state wanted in context of "political revenge" against the Dutch. The said article stipulated: "The Dutch-owned companies being under the territory of Republic of Indonesia, which will be put under the Government Regulation are going to be imposed with the nationalization and be fully and freely owned by the State of the Republic of Indonesia."The said law clearly stipulated the Onteigeningsordonantie (Stb.1920. No.574), or often called as the Ordinance of Rights Expropriation), was not applicable in context of the said nationalization. This ordinance provides warranty that anyone is not allowed to be expropriated of his wealth, properties and rights without due process of law before the court. According to the State this ordinance would only be applicable for individual expropriations - whilst this Nationalization Law had its own general characters. Other reason, the

regulations on the unattended land along Western Coast of Sumatra and the government land within the Residence of Eastern Coast of Sumatra. However, as a matter of fact, the Stb 1874 No. $94 \mathrm{f}$ was never implemented, at least within the three territory of the Sultanates (Deli, Serdang and Langkat), which was due to the opposition launched by the Sultans who had entered into political contract with the Dutch.

${ }^{30}$ Seet van de Kerkhof, Jasper. Indonesianisasi of Dutch Ecnomic Interests, 1930-1960: The Case of Internatio,. Bijdragen Tot de Taal, Land en Volkenkunde, 161.2/3. Leiden, KITLV, 2005: P.188. See also, Bank, J.Th. Rubber, Rijk and Religie; De Koloniale Trilogie in de Indonsische Kwestie 1945-1949. Bijdragen en Mededelingen betreffende de Geschiedenis der Nederlanden, 1996: P. 230-259. The endeavors made by the Dutch to enshrine its influences in Indonesia continued to be done through Renville Agreement (1948) and the Second Aggression following in December 1948, and finally was terminated with the Meja Bundar Accord in Den Haag, to be carried out 23rd August - 2nd November 1948, 
Ordinance of Rights Expropriation was to be established through a legal system upon the supremacy of individual rights - while this Nationalization Law was developed in a legal system, which was oriented to accommodating social function and private ownership (individual).

The new State, so called Indonesia, on pretext of a nationalization over the assets of the Dutch-owned enterprises situated thereinside, also brutally and "emotionally" seized the ownership of rights of customary land-holdings previously entrusted by the people upon the Sultanates, which was by real fact to have clear, long and historical basis. The agreed upon rules of contract of plantation concessions being practiced equally during that period, in its nature of being perssonlijk, was not anymore regarded as a consideration by the rulers. The initial underlying point was actually to take political revenge against the Dutch upon the failure of the Meja Bundar Accord, however, in the end, it also impoverished and seized the traditional rights of its own people. The land rights that has been for many years becoming an important part in the lives of the people in urung, Kampung and Kedatukan was all of a sudden forcedly moved into the hands of the ruling government, which was then transformed into a new rights to be well known as Rights of Business Entity( a conversion from the so called erpacht). ${ }^{31}$

Two years only following this very controversial law was announced, the State showed up its real character through Law No. 5 of 1960 on the Agrarian Matters, declared namely: a. the rights and power upon the land and water embodied within the Autonomous areas and those of the existing ex-autonomous areas when this Law comes into effect, are written off and be transferred to the hand of the State; b. any matters should they be related to the provision of word "a" to be mentioned above shall be governed and arranged by the Government's Regulation. This has been blindly against the facts that on the ex-autonomous land has grown such a respects over the customary land being legally and highly honored through article No. 3 and No. 5 of Law No. 5 of 1960 (recognition over the communal land and customary law).

Al local level, the formal annihilation of the tanahjaluran in 1968 through Governor's Decree No. 370/IIIGSU, which then was reinforced by the Joint Decreeof the Ministry of Home Affairs and the Ministry of Agriculture dated $25^{\text {th }}$ April 1969 and the law No. 52 of 1969 and of No. 141 of 1969, has become important milestones in this region - as the State's legal decisions that would annihilate the landmark of communal rights owned by most numbers of Malay residents living around the tobacco plantation. The Decree of the North Sumatera Governor, at that time was Marahalim Harahap, stating all of the TanahJaluran was to be planted with paddy by PTP IX was of a weird and misleading move. It was regarded weird because the PTP just did not have experience in paddy-planting. It was misleading because even before this happened, the said land has been cultivated with paddy by the Indigenous People - not with other plants. Other cash-crops were planted onto it so long as there was time space available after the paddy was fully harvested.

There comes a time, the Malay People as the early inhabitants to become the

\footnotetext{
${ }^{31}$ Van de Waal quoted what was so called erfpacht could only be implemented successfully within areas being subjected by korte verklaring, such as Simalungun (89 Plantation), Asahan ( 95 plantation) and Labuhan Batu (748 plantation). He also quoted that the so called the de landbouw concessieis een persoonlijk recht, berustend op een overeenkomst tussen de Sultan en de concessionaris (Plantation concession is a personal rights which is based on agreement between the Sultan and the concession Holder). See van de Waal, Robert. Richtlijnen voor Een Ontwikkelingsplan voor de Oostkust van Sumatra (proeftschrift), Wageningen: 1950.
} 
drifting beggars on their own land. They are accused of being criminals and be put in jail using the provisions of Criminal Code and using the Plantation Law No. 18 of 2004 up until the reform era. The State's law has become a dagger deeply stabbing into the heart of Malay People who were relatively weak in terms of their solidarity, social structure and cohesiveness. The State's law just did not relatively find it difficult to domesticate the customary groups of Malay People, most especially after the position of the existing Sultanates to be made drifting on the weakest point of recognition, which was resulted from the stigmatization of feudalism - a group that is enriching itself and those of the Dutch's collaborators and compradors.

The reform of 1998 and the issuance of Agrarian Minister's Regulation/the Chief of National Land Agency No. 5 of 1999 on The Principles of the Settlement of Rights of the Communal and Customary Land Problems would seemingly give a little hope with regard to the arrangement and harmonization between the State's Law and Customary Law regarding land disputes. However, when deeply looked, most especially with regard to technical rules issued by the central executive officials, it was all of so called a legal camouflage that again and again is showing its absolute supremacy - against people's demands with regard to the loss of their indigenous rights.

Article No. 3 of the Agrarian Minister's Regulation that stipulates: "The application over the rights of communal land of Customary Law People as stipulated within article No. 2, cannot be implemented any longer over the existing portions of land during which the Regional Regulation is issued as stipulated within article No. 6: to have been owned by individuals or legal bodies by any means and basis of rights over any land in accordance with the Principles of Agrarian Law; $b$. to be ofland portions that have earlier been obtained or released by any government's institutions, legal bodies or individuals in accordance with the provisions and the prevailing rules and regulation,","'to have been curtailing and hampering the chances of groups of Malay People in this region to obtain formal recognition by the State upon their existence over their communal land.

\section{Conclusion: Questioning the State's Legal Politics against the Communal Land and the Needs for National Regulation.}

The brief historical accounts on the transfers of communal land rights of Malay People in Eastern Coast of North Sumatra, as elaborated above, has clearly showed the identity, which was fortified by the State against the neglects of the cultivating rights of customary people descended by their ancestors for many centuries. The structural deprivation of peoples by means of government regulation had been initiated ever since the influx of colonials and it continuously practiced up until Indonesia's independence era. The deprivation of people and/or the neglects against communal land in Indonesia, in general, can be seen as a concerted movement done by the State through partial regulations and policies and strongly fortified by means of bureaucratic behavior at various empirical levels.

During the Dutch period, such efforts had been initiated ever since the enactment of Agrarisch Besluit of 1870. The definition of so called woestegrondto be meant as uncultivated land and therefore it became the State's property can be said as the beginning precedence of State's legal intrusion against communal land in Indonesia. No matter how hard the efforts made by Van Vollenhoven together with his students, either in Leiden and Indonesia, to provide explanation to the colonial government with regard to the existence of a communal land rights, which was very specific 
in nature, which is not found in the dictionary of Dutch Law and of the Europe in general, seemingly not yet able to curtail the greedy lust of the colonial government in controlling the laws of customary land by western perspectives.

The same purpose that was committed in such a more blurred manner also occurred when this country gained its independence in 1945 - at least after Soeharto and the New Regime took power. As quoted by Setiawan, it is reflected from the orientation and the agrarian political practice, which is strongly fortified through various products of sectoral regulations, governing and controlling directly the abundant richness of our country's nature.For instance, regulations that deals with forestry, oil and gas mining, irrigation, fisheries, etc. These said sectoral regulations carry the spirit and contains to facilitate big capitals rather than fulfill the rights of the wide public. Further, in the name of the State, the central and regional government new rights, such as: Rights of Ownership, Rights of Building Use, Rights of Business Entity, Rights of Usage, Rights of Forest Management, Rights of Industrial Forest Management, Rights of Mining Authority and Mining Working Agreement. ${ }^{32}$

The state's policies have created a deep wound in the part of customary people and it has become one of the sources of all confusions over the settlement of communal land conflicts. In context of communal land of ex-tobacco concession of Deli, the blindly implemented nationalization policy over the land rented to the Dutch-owned enterprises, which has been briefly elaborated above, has become the most structural trigger and is responsible for the chaotic situation in this region.

With regard to the political construct of communal land conflict occurred herein, the State clearly enjoys far more benefits for it has fought vis a vis with the entity of the much loose and weaker structure of Malay people, in terms of fraternity and cultural memories, most especially in context of land related matters, along with the ever blurring to be precisely saying, the paralysis of kingdoms of coastal Malay, in the eastern coast of Sumatera. The new State that so called Indonesia has apparently seized the abundant economic and natural resources, which can no longer be enjoyed by the local people. This has been more or less the same as when the foreign planters cunningly deceived the Sultan by only providing a little portion of land taxes upon new expansion of plantation.

The law has become so centralistic, while formal justice institutions fortifies and contributes to securing its processes. In the name of the so called Rights of Business Entity given away to the State-owned enterprises, the rich and fertile land for the tobacco planting is reformatted periodically. On the pretext of divestment, as a matter of fact, the land reform and unreasonable loss continues to be experienced by the plantation enterprises in this country, at a later stage, the land gradually and eventually was falling into the hands of business man. This is what is so called erzat kapitalisme as quoted by Yoshihara Kunio. The fate of local law is just like an old arboreal parasite plant that grows on a mother tree. This is paradoxical: the Malay people as the owner of the land turned out to be beggars or tramps on their own traditional and native

${ }^{32}$ See Setiawan, Usep. Dinamika Reforma Agraria di Indonesia Setelah Orde Baru (The dynamics of Agrarian Affairs in Indonesia after the New Order) in Tjondronegoro S.M.P and Gunawan Wiradi (the editor). Dua Abad Penguasaan Tanah: Pola Penguasaan Tanah di Jawa dari Masa ke Masa (Two Decades of Land Expropriation: Patterns of Land Appropriation in Java, from Time to Time) , Jakarta, Yayasan Obor Indonesia, 2008: p.403. Holistic Review on the Unsettled Land Affairs in Indonesia, see: Tanah Masih di Langit: Penyelesaian Masalah Penguasaan Tanah dan Kekayaan Alam di Indonesia Yang Tak Kunjung Tuntas di Era Reformasi. (Land Remains in Heaven: The Settlement of the Ever-unsettled Land Expropriation Affairs in the Reform Era) Jakarta, Yayasan Kemala, December 2005. 
land; just like the mother-tree turns out to be arboreal parasite plants. The fate of the so called oetan Tanahand or Rebaas well as people who struggle on it is just like what has been reflected by an old Malay maxim: "Antan Patah Lesungpun Hilang" (When the Pestle is broken, the Mortar is certainly gone)..$^{33}$

The State's laws, which are formally adopted in relation with the existence of communal land rights, have lost its roots like legal pluralism, cultural relativism and its essential aspects - such as communalistic character and religious - magical situation. Heterogeneity and pluralism may not have banished the roots of the prevailing law, for they are serving as important resources in the development of just and fair laws. The neglects against plurality will pose direct a consequence in the form of complete disregard over proper justice, which has clearly been violated one of the main objectives of the law itself.

The true intention to protect the whole elements of the country, as obviously stipulated in the preamble of the Constitution of 1945, has been falling apart away from the expectation of many people. The law that serves as a tool of social engineering, as quoted by Roscoe Pound tens of years ago has changed its nature and meaning - to a means of repressive social control and vulgarly turns down the variety of differences. The State builds its own concepts by affixing recognition of cultural institutions onto it by the words: so long as not against public interests. The relatively blurred words, such as these, are then used by the State to win the positions of new players under the State's wish, most especially in the scope of living struggle over the ownership of land rights, which is massively prevailing across the country. The economic consideration in the name of the State's pseudo interest has become a primary postulate to disregard the people's cultivating rights over the existing communal land.

At normative level, the presence of article 18 point $b$, verse 2 of the 1945 Constitution, (stipulating: the State recognizes and respects the units of customary people and the traditional rights so long as still prevailing and in compatible with the development of the people and the principles of the unitary State of Indonesia, as regulated by law), is indeed providing a new hope for the clarity and protection upon one of the rights of land of the Indigenous Indonesian, as quoted by Van Vollenhoven about a century ago. Our prediction to realize special law for the recognition and protection of the rights of customary legal people, as to clarify the aforementioned article 18 , is still wide open, regardless of a winding route ahead. ${ }^{34}$

\footnotetext{
${ }^{33}$ This is a proverb of Malay people that means a situation in which someone is burdened with misery again and again. This in an allegory or metaphor that may delineate the situation of people in Eastern Coast of North Sumatra in relation to their land rights, which is successively experiencing pressures, shrinkage and shifting, ever since the coming in of Dutch planters in third half of the 19th century.

${ }^{34}$ The Plenary Session of People Consultative Assembly of Republic of Indonesia, Thursday, 11th April 2013, chaired by the Chairman of House, Pramono Anung, agreed for the enactment of the Bill on the Recognition and Protection of Customary People to be the Initiative of the House of Republic of Indonesia. The Golkar Party's fraction agreed the Bill, however there is a need to set up six important principles: First, the protection of the rights of customary people shall be in the form of compulsory service given by the state. Secondly, the customary people shall be entitled the rights to determine and develop priority and strategy for the development and usage of their lands, areas and natural resources by means of proper ways in accordance with local wisdom; thirdly, customary people shall be entitled the rights to preserve and develop tradition, customs as well as cultures of their own; fourth, the empowerment of customary people is carried out by the government, regional government and the people themselves; fifth, the financing source in indentifying, verification and adoption of the customary people as well as the implementation of program with regard to providing services, capacity building promotion shall be borne by the APBN and APBD; sixth, with regard to the establishment of customary justice, it is expected to provide protection for customary people's need with regard to their native rights, which has always been violated. See http://www.dpr.go.id/
} 
Half a century, following the enactment of Law No. 5 of 1960, the State intentionally lets loose the unclear existence of what is so called beschikkingsrecht, which serves as a landmark of the presence of customary people in Indonesia. Therefore, the presence of Law on the Recognition and Protection of Rights of Customary People has become a normative answer, which has longingly been awaited, most especially by the groups of customary people whose struggle up to the moment is to gain recognition from the State. Various initiatives made by any people's groups wishing to get ahead of the emergence of the said law - by proposing the formulation of such a related local law at the province, city and or district level shall be given a proper appreciation. Last but not least, it should be noted also, how bad quality of recognition conducted by the State coming down through its lower agencies, most especially in appreciating, formulating and producing a variety of various Regional Regulation. ${ }^{35}$

\section{Bibliography}

Bank, J.Th. Rubber, Rijk and Religie; De Koloniale Trilogie in de Indonsische Kwestie 1945-1949.Bijdragen en Mededelingen betreffende de Geschiedenis der Nederlanden, 1996.

Bool, H.J. Landbouwconcessies in de Residentie Oostkust van Sumatra (tanpa tahun dan tempat)

Buffart, J.F.A.M.. Rechten van de Bevolking op in Landbouw Concessie Uitgegeven Gronden. Overdruk uit "Indische Gids", Juli - Aflevering 1933.

Burns, Peter. The Leiden Legacy: Concepts of Law in Indonesia. Leiden, KITLV Press, 2004.

De Ridder, J. De Invloed van de Westersche Cultures op de Autochtone Bevolking ter Oostkust van Sumatra, Wageningen: H.Veenman\&Zonen, 1935

Husny, Lah. Lintasan Sejarah Peradaban dan Budaya Penduduk Malay PesisirDeli Sumatera Timur 1612-1950, Jakarta: Departemen Pendidikan dan Kebudayaan, 1978.

Ikhsan, Edy. Antan Patah Lesungpun Hilang: Pergeseran Hak Tanah Komunal dan Pluralisme Hukum dalam Perspektif Sosiolegal (Studi pada Etnis Malay Deli di Sumatera Utara), Ringkasan Disertasi, Program Studi Doktor (S3) Ilmu Hukum, FH USU, Medan, 2013.

Jansen, Gerard. Granrechten in Deli. Uitgave van Sumatra-Instituut. 1925.

Kleintjes. Staatsinstellingen van Nederlandsch-Indie. Amsterdam, 1924.

Labberton, K. van Hinloopen. De Indische Landbouw consessie. Amsterdam, JH. De Bussy. 1903.

Lekkerkerker, J.G.W.Concessie en Erfpachten ten behoevevan Landbouwondernemingen in de Buitengewestenvan Nederlands Indie, Groningen-Den Haag, JB.Wolters, 1928

Mahadi. Sedikit Sejarah Perkembangan Hak-Hak Suku Malay atas Tanah di Sumatera Timur (1800-1975), Bandung, Penerbit Alumni, 1976.

Pandecten van het Adat Recht IV.

Perret, Daniel. Kolonialisme dan Etnisitas: Batak dan Malay di Sumatera Timur Laut. Jakarta, Kepustakaan Populer Gramedia, 2010.

\footnotetext{
${ }^{35}$ One worse experience was that of experienced by North Sumatera Regulation No. 12 of 1997 on the Conservation of Areas of Tobacco of Deli in North Sumatra. The basic intention that is intended to protect one of the unique plants of the world heritage in North Sumatera has gone down to the annihilation of the plant itself. The tobacco plant as meant by the regulation cannot be withheld and now is approaching to extinct.
} 
Reid, Anthony. Perjuangan Rakyat: Revolusi dan Hancurnya Kerajaan di Sumatera. Jakarta: Sinar Harapan, 1987.

Slaats, HMC dan MK.Portier. Grondrecht en Zijn Verwerkelijking in de Karo Batakse Dorpssamenleving.Nijmegen, Ge Nabrink \& Son, 1981.

Setiawan, Usep. Dinamika Reforma Agraria di Indonesia Setelah Orde Baru dalam Tjondronegoro S.M.P dan Gunawan Wiradi (Penyunting). Dua Abad Penguasaan Tanah: Pola Penguasaan Tanah di Jawa dari Masa ke Masa, Jakarta, Yayasan Obor Indonesia, 2008.

Stoler Ann, Laura, Capitalism and Confrontation in Sumatra's Plantation Belt, 18701979. The University of Michigan Press: 1985.

Termorshuizen-Arts, Marjanne. Rakyat Indonesia dan tanahnya: Perkembangan Doktrin Domein di masa kolonial dan Pengaruhnya dalam Hukum Agraria Indonesia, dalamSafitri, Myrna A dan Tristan Moeliono. Hukum Agraria dan Masyarakat Indonesia. Jakarta, HuMa, Van Vollen Hoven Institute dan KITLVJakarta. 2010.

Van de Kerkhof, Jasper. Indonesianisasi of Dutch Ecnomic Interests, 1930-1960: The Case of Internatio,. Bijdragen Tot de Taal, Land en Volkenkunde, 161.2/3. Leiden, KITLV, 2005.

Van de Waal, Robert. Richtlijnen voor Een Ontwikkelingsplan voor de Oostkust van Sumatra (proeftschrift), Wageningen: 1950.

Van Vollenhoven, De Indonesiers en Zijn Grond, Leiden, Brill, 1919. 